\title{
Editorial
}

\section{1st century brandknowledge - towards the ADEP*T standard for brands' promise and trust}

\section{INTRODUCTION TO WHAT 21ST C BRAND KNOWLEDGE IS NOT}

As we enter the 21 st century, it is important to understand that two very different definitions of branding exist. The next two paragraphs oversimplify just a bit.

The first concept of branding is whatever the advertising agency says perfect brand execution is. Typically, this is targeting the consumer, creating images, leveraging perceptions, extracting a premium price from the consumer over the lifetime of the campaigns that the brand client buys from the agency, etc. Some would say this concept has been the essence of 20th century mass marketing (though interestingly those like Drucker ${ }^{1}$ who helped coin the term marketing in the middle of the century had a different organisational purpose in mind).

The second concept of branding is the one which grows the brand - or more technically a company's systematic knowledge organisation around and investment in brand architecture ${ }^{2}$ - as the most valuable corporate asset.

In this second role ${ }^{3}$ branding identifies what the company as a leader communicates, acts on, takes a stand on in the eyes of all its communities, and what it purposefully changes, as living organisms must, to compete. Branding emotionally connects all the intangible assets of the company and its authority in the information age. Branding is the promise consistently to deliver unique value to the world. Branding is the pride that is communally shared by all employees of an organisation and the passion in perceiving how to make an individual contribution that enables the com- pany and and its competence to grow. Branding is the relationship system designed to grow value equably for all constituencies who trust the company brand with their loyalty. 21st century branding will also be the web and nets which do this. I hope you will agree that the ideas in Table 1 give exciting food for thought. They support the hypothesis that the communications revolution that we are enacting today makes the circa 1950 revolution of television advertising look like a blip on the Richter scale.

This special issue is devoted to frames for organising the systematic integrity of this second - and 21 st century - concept of branding. Managers from many business disciplines may need to do some millennial soul-searching, not the least marketers. My virtual research among practitioners E-mail discussion groups over the last five years has revealed (see Table 2 - reasons) why marketers are disliked or distrusted by their fellow knowledge-workers.

Demand for the corporate and social need to reform brand knowledge is also emerging from a diverse movement of opinion leaders. One of the most important things leadership communications does (when it truly aligns the company) is to help resolve paradoxes. ${ }^{4}$ Paradox busting has always been a way human beings evolve to a higher level of intelligence - why not human organisations in the age of knowledge workers too? Here, leadership's core communications role is about focusing the organisation's mind on simplicity in what would otherwise be a business world of 


\section{Table 1 Managers of this earth ...}

Know ye the glossary meanings of four forces defining the turn-of-millennium revolution in marketing learning organisations:

A) Networked online market conversations;

B) Internet;

C) Intranet;

D) Connections to make with e-brand (or 21st century brand leader).

\section{A) Managers of this earth - interact with the first lesson of cluetrain.com} (soon to be a 100k run book for those who cannot surf)

'Online Markets build up as powerful global conversations because ... networked markets are beginning to self-organise faster than the companies that have traditionally served them. Thanks to the web, markets are becoming better informed, smarter, and more demanding of qualities missing from most business organisations.'

\section{B) Managers of this earth - listen to a founding father's core value of the net}

'The Internet is a place, an environment, made up of people and their myriad interactions. It is not merely a technology but a new way of cooperating, sharing and caring. Businesses that recognise the human aspect of the Internet will be more likely to find success in the artificial worlds of the Digital Age, for they will understand that the artificial is rooted in reality, and reality is rooted in our hearts.'

Vint Cerf, 'Father of the Internet'

\section{C) Managers of this earth - experience why intranets change what is organisationally} possible

'Intranet technology is altering the culture of international corporations, qualifying employees worldwide to understand key issues facing their business, exchanging ideas in real time, and to collaborate on solutions ... You cannot implement the technology for the sake of technology. You must align the visions, the mission, and the goals of the organisation to identify the best way for your organisation to evolve and mature into a 21st century organisation ...There is no need for reengineering the organisation. The focus is to move the decision making, the actions, the problem solving and the responsibilities closer to the people who understand the opportunities and possess the skills to react quickly and efficiently. When a problem needs an organisational solution, users can reach out to the expertise, power and wealth of the intranet and focus total resources on the problem. The intranet is about being linked together like some great collective consciousness, where people can cultivate their intelligence or call on networked intelligence as a powerful resource.

\section{Randy Hinrichs, author of 'INTRANETS'}

\section{D) Managers of this earth - design all leadership communications with this idea as top-of-mind awareness among all you work with}

'The e-brand (or 21st C brand leader) communicates to its community of relationship-owners (ie all the constituencies whose loyalty it seeks) and through a living media (ie connecting internet, intranet ...) made up of people and their myriad interactions. Our most human qualities are now needed to help us recall that the most valuable interactions will be those which revolve round making heroic promises and keeping the trust.'

Reproduced with permission of http://www.brandknowledge.com 


\section{TABle 2 Mass media made MARKeting toO EASY fOR the LAZY}

\section{Dimensions of dislikable marketing:}

— added cost, endemic wherever defensive marketing is practised;

— obsession with sexiness of external media and being wined and dined;

— rivalry between internal brand empires for resources etc;

— awful at exchanging knowledge internally (arrogant, won't be there ...);

— too big a job so others take over piecemeal (strategy, quality ...);

— lost organisational confidence in offensive (AV) marketing;

— not taking advantage of change, irony: changes, eg globalisation/digitalisation, never greater;

- not participating in Drucker's two main jobs of marketing leadership:

- circulating external knowledge needed so that every employee can action learn;

- supporting leaders in emotionalising how the next change challenge is an opportunity to grow the company.

Source: Author's slide show on findings from E-mail surveys first presented to marketing professors at Harvard, February $1999^{7}$

complexity and internal politics.

You can start to see the paradoxes that trustworthy 21 st century branding will need to master emerging in such varied thinking spaces as:

- 'Built to Last' by Collins and Porras ${ }^{8}$ where paradoxes of leadership such as 'preserve the core while stimulating progress' provide the book's structure.

- The discipline of simplicity championed by Americans such as Bill Jensen ${ }^{9}$ and Thomas Petzinger. ${ }^{10}$

- Revolutionary consumer movements of the networking age such as http://www.cluetrain.com

- How the most successful e-business concepts appear to work. Because they are confident that they deliver win-win value across all their constituencies, they make information transparent, ideally having nothing to hide from anyone they serve.

- Work on transforming organisational IQ by Haim Mendelson and Johannes Ziegler ${ }^{11}$ chronicled in their new book 'Survival of the Smartest'.

- The research programmes of Enterprise IG which seek to 'out' the different corporate identities that a company poses under as a precursor to Brand Alignment $^{\text {TM }}$.

- White papers issued by Oracle on the connection between brand, databank intranets and performance measurements.

- The founding editorial policy of Henry Stewart's journal Corporate Reputation Review, and - at least as I read it - of this journal.

- One of Tapscott's summary conclusions 


\section{Branding is the business of growing smart relationship connections aligned around a Promise Systematically-worth Trusting}

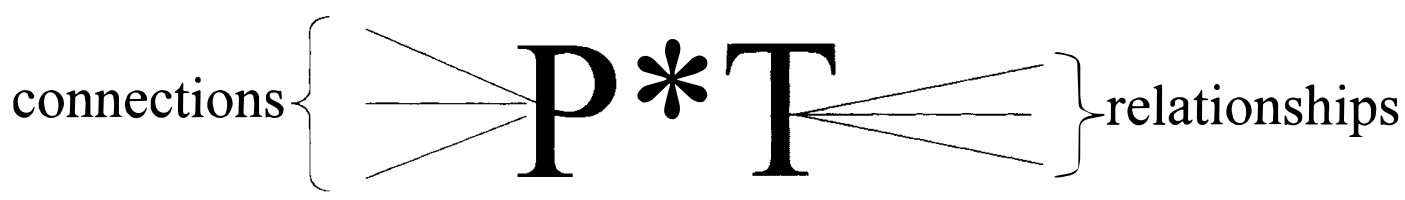

Eg employee knowledge, motivations, culture, systems, processes...
Constituencies include consumers, employees, network partners, shareholders, society, opinion leaders editing the book 'Creating Value in the Networking Economy: ${ }^{12}$ the 20 th century ideology of brand image will increasingly be replaced by the $21 \mathrm{st}$ century ideology of brand relationships made transparent by information access to all constituencies of the brand.

- The new leadership philosophy of Fractal Marketing for acting responsibly as a global and local network advocated by Mazda's UK President, David Heslop: http://www.brad.ac.uk/branding/bradfordlectures.html

- The communal belief which members of http://www.brandknowledge.com are interacting around namely: the only 21 st century organisations of any real value will prove to be those which make the most of brand, knowledge and their people ... and harness webs/intranets to deliver the promise of heroic customer service.

Conversely, you can see places where failure to distinguish between 20th and 21st century concepts of branding appears to create an editorial or leadership muddle. One example seems to be the Harvard Business Review. On the one hand, this thinking person's medium now attaches importance to the brand as major corporate asset by including a feature article involving the brand in almost every other issue. On the other hand, most of these contributors seem to be busy burying the brand in the complexity of paradoxes (by insisting on either one or the other, rather than leadership integration of the two). Fortunately, our interactive age provides a way for insisting that this muddle be resolved quickly. See, for example, how Harvard's readership have been transparently answering back to such paradoxically biased article titles as: 'The Lure of Global Branding': (to which readers ask, Don't leaders need the best of global and local branding?) http://www.hbsp.harvard.edu/webboard/w ebboard.dll/ forum_novdec1999.

'How e-Commerce will trump Brand Management', (to which readers ask, Don't leaders need to integrate both?) http://www.hbsp.harvard.edu/webboard/we bboard.dll/ forum_julaug1999 
TABLE 3

PROMISE

Alignment and convergence

of identities

Essence/UOP (Unique

Organising Purpose)

Reality of Brand Positioning

(ie employee pride and passion)

Values driving culture and corporate personality

Brand Mantra

Hoshin Planning, ie the way

Japanese action change challenges

Productive competences

Visionary focus: map of sub-goals
Nets: internet, intranet, extranet...

Webs: communities of practice

Knowledge for action: fast company structure

Learning organisation and system disciplines

Simple common language

Paradox-busting leadership tools, eg Catalytic Mechanisms

Best practice e-business and e-society models

Systems dynamics

Programming interactive measurement systems
TRUST

True best friend relationships

Reputation among stakeholder constituencies

Win-Wins across value exchange network

Transparency of information

Measuring value to (not just from) the other party

True leadership of quality and value

Total 2-way integrity of communications and doing

Fractal Marketing

Economics of intangibles

Listing not intended to be comprehensive - aim is to give reader a multidisciplinary window to selecting interconnected atoms of $\mathrm{P}^{\star} \mathrm{T}$

\section{A SIMPLE STANDARD FOR WHAT 21ST CENTURY BRANDKNOWLEDGE IS - PART 1 - P*T}

Clearly the 21 st century may bring many changes to brandknowledge. And the next decade in which e-business and e-society blossom worldwide and in localities near you will be as exciting as any time I can think of. The turn-of-millennium generation has the extraordinary privilege of experimenting with far more means for really human media than the mass marketing revolutionaries enjoyed with the mid-20th century advent of the television spot. ${ }^{13} \mathrm{We}$ need to see this as a privilege which connects every human expertise and aspiration, not just an issue for grey suited businessmen or colourful creatives.

Whatever branding connects, the three simplest core constructs I can imagine are $\mathrm{P}^{\star} \mathrm{T}$ :

- $\mathrm{P}=$ Brand Promise;

- $\mathrm{T}=$ Brand Trust;

— $\star$ - The web and net communities of information which as an integrated living whole make the relationship of a brand promise really worth trusting. I 
use $\star$ because our language doesn't really have a term yet for expressing the common emotional currency which will come from interconnecting e-business and e-society and by making seamless links between webs, internets, intranet, ${ }^{14}$ extranets, communities of practice ... The lack of terminology should not stop you from imagining how electronic knowledge transparency will flow. (See Figure 1).

Moreover, each of these constructs is tricky in that it requires us to unlearn some 20th century brand expertise as well as building on our marketing and learning organisational disciplines.

Brand Promise requires us to stop thinking of merely positioning prospects' perceptions and to make the brand real inside. ${ }^{14}$

Brand Trust requires us to make measurements which are far more balanced than any corporate scorecard I have seen to date. There's a lie at the heart of many a 20 th century corporate's notion that you create value by taking it from someone like your customers. Moreover business quarters are a poor time period for measuring relationship strength, and if your company's culture is only concerned with maximising profits, wearing my consumer hat I would be the dumb opposite of interactively smart to perceive you as worth trusting. Arguably, balanced is even the wrong word for monitoring something which is only going to sustain trust if it is continuously interacting communal winwins ${ }^{15}$ between the company's different stakeholder constituencies.

Knowledge needs to be focused both in terms of what a company's purpose is within a wider network and for actionability by every employee and in every business activity. Few 20 th century leaders yet understand how revolutionary a change information transparency will bring to those corporate cultures which will have earned a high reputation (aka 21st century e-brand equity) in 2010.

This $\mathrm{P}^{\star} \mathrm{T}$ model has influenced me in selecting the breadth of papers appearing in this issue. And reading this issue may convince you that Brand Knowledge should be brought out into the open as the great and humanising - multidiscipline of the 21 st century businesses. Table 3 , as a display of partial synonyms, may instill a deeper feel for the connectivity which $\mathrm{P}^{\star} \mathrm{T}$ requires us to charter into the way brands are led.

\section{THE CONTRIBUTORS TO THIS ISSUE}

Ben Schneider explains what organisational behaviourists already know about the link between employee and customer motivations, and the win-win values that can be gained from doing this right. While this link has often disappeared in 20th century organisations, it is the core link between internet and intranet in almost every robust e-business model I have ever researched. There is now a huge opportunity for brand marketers and organisational behaviourists to share their learnings. By doing so they can demand that netbuilders preserve the human point of all their fantastic technology.

Charles Fombrun examines the research basis for developing a Reputation Quotient. What are the factors of trust that different audiences of a company relate to and how can a company synthesise these into a composite benchmark and maturity profile? As Charles points out this hugely significant area has previously been under-researched, reputation league tables having been popularised by business magazines such as Fortune.

Dave Allen updates us on a five-year research programme designed to develop a framework for a leadership team of a global company to implement brand promise starting from the hypothesis that active and aligned participation in the 
Figure 2

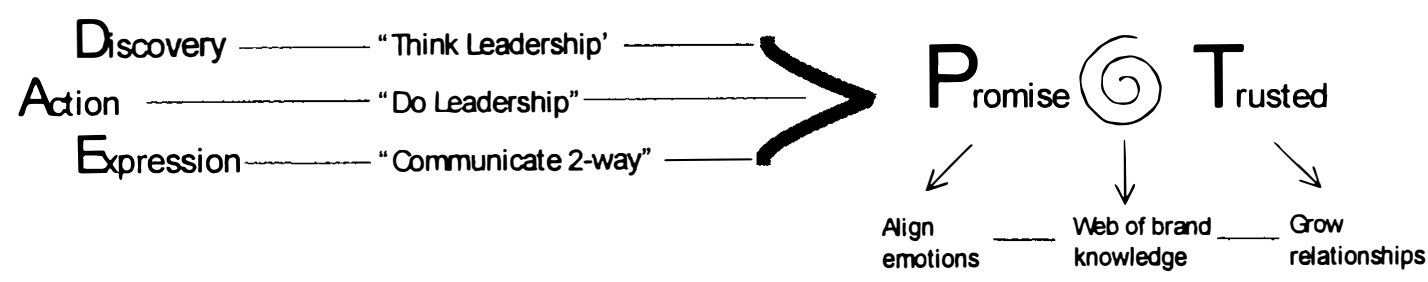

brand promise is new to everyone in the company. In other words, a common language of what the company stands for needs to be developed from scratch so that everyone in the company can discover what corporate identity they want to commit to. The discovery process requires that several different corporate identities be outed and the gaps between them narrowed. This work cannot be done purposefully unless it involves clarifying the motivations of everyone in the company and the cultural drivers which resonate through the organisation.

Peter Fisk goes deeply into how values are the brand magnet of great companies being both the emotional sustenance of a company's brand promise and the reason why it worth placing trust in a relationship with a company.

Melissa Richardson provides us with some in-depth experiences on how the internal campaign for clarifying and sustaining brand promise needs continuous support, propagated through all employees' senses (not just verbal ones). Doing this right can make the promise of an internal brand lifestyle a highly imaginative process at group and individual levels.

Brad VanAuken provides us with a timely checklist for a full 360 degree view of brand management. As companies embrace the wake-up call of e-business, it is the right time to completely review the people responsibilities for the brand. Do this by understanding the new dynamics of net-enabled companies and the full breadth of connections that the brand must make in real organisational settings as well as virtual ones.

As this is the first special issue of the third millennium, I asked two contributors to help us stretch our visions a little further out.

David Weinberger, one of the four cofounders of Cluetrain.com now also published as a book with a 100,000 print run, explains why a the net generation of consumers is already redefining the marketing concept in conversational terms. With the new transparency of interactive dialogue, they hate to be targeted, brand managed and to be the object of almost every other one-way penetration that mass marketing speak used to congratulate itself on. At time of writing this editorial (December 99), Cluetrain has also just started up a worldwide E-mail conference. ${ }^{16}$ It is a space for many huge controversies concerning the principles which human beings want an e-mediated world to respect. A seminal case is how the Goliath of etoys.com (\#1 e-retailer of toys) is trying to erase the unlikely David of etoy.com (an avant guard European cultural web). ${ }^{17}$

Simon Torrance is a director of brightfuture.com, one of the few world class eage networks of communities to have been born in Europe. Bright specialises in creating communities so that internal marketing knowledge is shared on intranets etc. Simon provides an insight into how trust needs to be branded pervasively across any virtual knowledge building network before business to business at the speed of light 


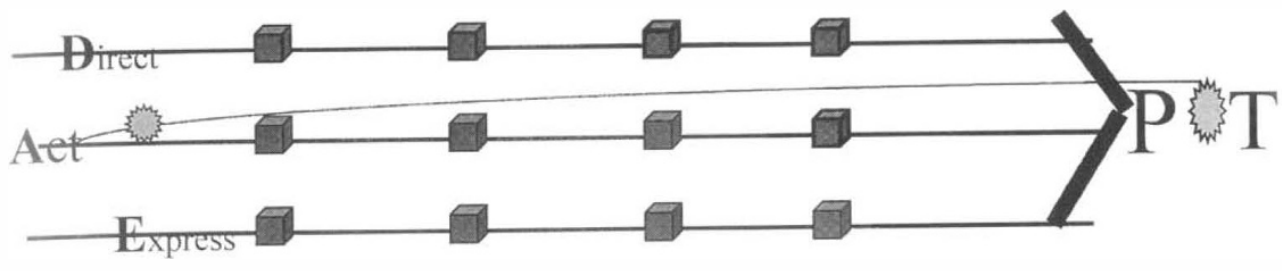

Figure 3

$=$ Building blocks or learning blocks?

EXERCISE: Who's blocking brand promise, *knowledge and trust in 20th C Organisations?

Which blocks are most disconnected from which others? Which blocks measure success in ways that destroy trust?

d-line (eg accountants, investment banks, management consultants, tangible strategic planning, megatrend future scenario advisers, other...)

e-line (eg ad agency, design, direct marketing (1to1), market research, other...)

a-line (eg performance appraisals, rewards, training facilities, change agents, knowledge-builders, IT, other...)

gets liftoff. His future-case paper also suggests how new forms of intermediaries have the potential to be powerful business to business brands.

\section{A SIMPLE STANDARD FOR WHAT 21ST CENTURY BRANDKNOWLEDGE IS - PART 2 - ADEP*T}

One day realising the brand as the networks where communities of people exchange promises and keep the trust will come naturally. As you read through the details - and indeed the immediate future shocks - catalogued by our contributors, that day may seem far away. Arguably that's all the more reason why we should blueprint a common standard for getting to the promised brand sooner rather than later.

The idea ${ }^{18}$ of putting the ADE suffix to $\mathrm{P} \star \mathrm{T}$ is that it provides a way to map out the current gaps (or literally map the state of disintegration) currently impeding an organisation. What are the gaps (of understanding, of enabling information flow and of people interconnectivity) between:

- marketers responsible for the way the company Expresses itself;

- the leadership team responsible for the way the company Directs and constantly Discovers communal identity;

- and every employees' Actions (potentially facilitated by experts in such lively areas as Human Resources, IT, Knowledge Management).

Recent research ${ }^{19}$ confirms that one of the biggest barriers to best branding practice is the way that different consultants and creatives who supply brand owning companies fail to work with each other or, indeed, to have a simple way of understanding each other. Try and make an honest map of this (see Figure 3 for illustration). This state of disintegration becomes a real eye-opener when you reflect on just how many of these suppliers' business cases depend on not integrating their knowledge, let alone webbing this as simply as possible into 
TABLE 4 BRANDKNOWLEDGE.COM MAP

\begin{tabular}{|c|c|c|}
\hline CONTENT & $\begin{array}{l}\text { ACCESS } \\
\text { (FORMATS) }\end{array}$ & INTERACTIVE POTENTIAL \\
\hline \multicolumn{3}{|c|}{ RESOURCES } \\
\hline Glossary & web; e-mail & $\begin{array}{l}\text { Help us sımplify standard definitions ; and link to historical orıginators of terms } \\
\text { and their contexts }\end{array}$ \\
\hline $\begin{array}{l}\text { Speeches \& } \\
\text { Papers }\end{array}$ & $\begin{array}{l}\text { pdf download; e-mail } \\
\text { reviews }\end{array}$ & Review paper. Exchange learning with fellow readers and author. \\
\hline Reading Lists & web; e-mail & Assemble top 100 multidisciplinary texts connecting brandknowledge \\
\hline Logic \& Magic & $\begin{array}{l}\text { bi-format : press and } \\
\text { pdf }\end{array}$ & Suggest opinion leading authors whose frames CEOs find logical or magical \\
\hline Soundbites & web; e-mail & Debate the issues to reflect on symbolised by the soundbite \\
\hline \multicolumn{3}{|c|}{ HOT DEBATE } \\
\hline Current Debate & web \& "chat box" & Help us to reveal all expert perspectives of the brand knowledge revolution \\
\hline \multicolumn{3}{|c|}{ NEWS \& LINKS } \\
\hline Hot Links & web links & $\begin{array}{l}\text { Assembly of uptodate top } 100 \text { bookmarks nominated by members of } \\
\text { brandknowledge community }\end{array}$ \\
\hline News \& Feeds & $\begin{array}{l}\text { web; e-mail (events } \\
\text { etc) }\end{array}$ & Directory of happenings and recent brandknowledge news/abstracts \\
\hline Journal Abstracts & web (journals) & $\begin{array}{l}\text { Fuller abstracts of journals who have freed us from copyright barriers in providing } \\
\text { fast content indices }\end{array}$ \\
\hline $\begin{array}{l}\text { Speeches of } \\
\text { Founders }\end{array}$ & web; e-mail & Current speeches by signatories and sponsors of the brandknowledge com mission \\
\hline Coming Soon & web & Major New Content: Expected time of arrival \\
\hline Recent Additions & web & $\begin{array}{l}\text { Internal links to our most recent content additions and hot news from our } \\
\text { researcher networks }\end{array}$ \\
\hline
\end{tabular}

organisation-wide action. Anyone working in a company can use this kind of a map to work out whether the board really supports the transition from typical 20th entury disintegrated brand state to integrated 21st Century Brandknowledge. If your board doesn't truly support this, it is probably best to consider another employee brand relationship than to continue to work for a company which has no right to exist in the transparent integrity that eworld will demand.

\section{LOOK BEFORE YOU LEAP INTO MEASUREMENT}

Measurement is a very powerful thing. It can very easily inhibit change rather than enable it. It can easily disalign (or politicise) employee motivations rather than harness them. It can very easily represent one professional group's attempt to subordinate others. To some extent, I would argue that through the 1990 s brand valuation, ${ }^{20}$ brand equity and marketing metrics have been guilty of all these easy faults. So let me ask you to stand back and participate in a different measurement exercise.

Exercise: If you could test with five pieces of litmus paper for the corporate brand IQ of a 21 st $\mathrm{C}$ organisation, what areas would you profile?

E-mailme atwcbn007@easynet.co.uk if you would like to compare your five profiles versus mine. I would currently summarise as my probes for excellence as: 
TABle 4 BrandKNOWLEDge.COM MAP - CONTINUED

\begin{tabular}{|c|c|c|}
\hline \multicolumn{3}{|c|}{ LEADERS \& THINKERS } \\
\hline Purpose & web;e-mail & $\begin{array}{l}\text { Introducing the world's first multidisciplinary electronic brainstrust on } 21 \mathrm{st} \\
\text { Century brandknowledge and the free rules of engagement }\end{array}$ \\
\hline Who's Who & web & $\begin{array}{l}\text { Bios of our panel of Leaders \& Thinkers. Members nominations for areas of } \\
\text { additional expertise representation }\end{array}$ \\
\hline Community Log & & Log of hot questions members are asking the panel \\
\hline \multicolumn{3}{|r|}{ MEMBERS } \\
\hline $\begin{array}{l}\text { Members } \\
\text { Registration }\end{array}$ & $\begin{array}{l}\text { Short database } \\
\text { questionnaire }\end{array}$ & $\begin{array}{l}\text { Gateway to joining eg community of practice networks focused by expert content } \\
\text { and personal curiosity }\end{array}$ \\
\hline $\begin{array}{l}\text { Sign into } \\
\text { Networks }\end{array}$ & $\begin{array}{l}\text { e-mail electing into } \\
\text { networks }\end{array}$ & Identifying globally and locally hot research/practice agendas of brandknowledge \\
\hline The Notice Board & web; e-mail & Display personal request to build quorums for new network agendas \\
\hline Origin Pages & web; e-mail & $\begin{array}{l}\text { Those who helped coin relevant terminology explain their intended context of use } \\
\text { and invite sightings of earlier claims to defining the subject }\end{array}$ \\
\hline $\begin{array}{l}\text { Communities of } \\
\text { Practice }\end{array}$ & web; e-mail & \begin{tabular}{|l} 
Priority networks of special interest (eg urgent goals) to founding members of \\
brandknowledge.com
\end{tabular} \\
\hline Online Surveys & web; e-mail & $\begin{array}{l}\text { Worldwide online benchmarks on opinions relating to leadership aspects of } \\
\text { brandknowledge }\end{array}$ \\
\hline \multicolumn{3}{|c|}{ ASK BEN/HELP } \\
\hline $\begin{array}{l}\text { Words of } \\
\text { Welcome } \\
\end{array}$ & web & The participatory and inclusive mission of brandknowledge.com \\
\hline $\begin{array}{l}\text { Communal } \\
\text { Priorities }\end{array}$ & web;e-mail & Current focal points and feedback on our values \\
\hline Q\&A & web; e-mail & Most common member Questions/Answers \\
\hline
\end{tabular}

- intranet;

- brand promise;

- primary value to lead a global network is 'value in cost out';

- energetic buzz of employees who know their organisation enables them to learn and do 'insanely great or really valuable stuff';

- transparent monitoring of every constituent stakeholder's trust in getting value from the brand.

NB: Clarifying what you believe to be the five top areas to profile in appraising organisational value creation is only a start, but it is also the right starting place for then debating how next to construct systematic measurement instruments. As an example of how times are a-changing, I am informed that what I call a company's 'intranet' capability (but others may equally well call ebusiness readiness) has in the last few years risen from nothing to be the biggest single factor that many US analysts use in rating a corporation's future growth potential.

\section{CONCLUSION}

21st Century Brandknowledge is changing so fast that it is beyond the scope of one person or one expert discipline to master it. This is a big challenge - not the least for those who share my belief that the brand is the most natural way in which leaders can connect all the intangibles of the networking age - organising the 
most that your company's brand and knowledge and people have to offer. What the worldwide web permits disciplined people to do is to integrate their disciplines and to network accelerated learning to each other.

After five years of practice as a webmaster $^{21}$ I hope to play a small part in this accelerated learning as one of the founders of the $21 \mathrm{st}$ century site www.brandknowledge.com (see map of version 1 in Table 4). Our mission includes providing an interactive space for assembling various worldwide research networks geared to putting $\mathrm{ADEP}{ }^{\star} \mathrm{T}$ into multidisciplinary practice. For example, why not join our list of reviewers in their communal assembly of a Good Management Guide instead of the UK's Food Guide reviews of restaurants our members aim to review all the most famous 20th century classical management and professional frameworks for gaps vis à vis $\mathrm{ADEP}{ }^{\star} \mathrm{T}$ connectivity. Or join another network which is concerned with assembling a corporate brand IQ test. Or post a question on e-business to our multidisciplinary brainstrust. Or simply come and debate the papers you see in this journal with their authors.

I would like to sign off this millennial space by posing one further question: what do you think is the biggest mistake business theorists taught 20th century MBA students? Answers by E-mail only please to me atwcbn007@easynet.co.uk.My own candidate - reflecting my father's decades of writings at The Economist and hopes for net-age free markets - concerns all models of defensive strategy. While I am not against getting time to breathe through defensive tactics, it is clear to me that investment in defensive strategy is a synonym for adding cost, or slowing desirable innovation, or disaligning your leadership promise and creating distrust between people, or all of these things. I sincerely believe that the information transparency and interactivity of the Internet age means that organisations that persist in this complex indulgence are business dinosaurs whose rapid extinction will be an early outcome of our third millennium.

\section{References}

(1) Drucker, P. (1999) 'Management Challenges for the 21st Century', Harperbusiness.

(2) Macrae, C. (1996) 'Brand Chartering Handbook - How Brand Organisations Learn Living Scripts', Ch. 11, Addison-Wesley; and Uncles, M., Cocks, M. and Macrae C. (1995) 'Brand Architecture - reconfiguring organisations for effective brand management', The Journal of Brand Management, Volume 3, Number 1; and Matthews, G. (in prep.) 'Brand Architecture - Managing the Marketing Communications Process', previewing at http://www.brad.ac.uk/branding/archit ecture99.html

(3) See, for example, the multidisciplinary reading list http://www.brandknowledge.com/rdis t_a.htm

(4) http://www.brandknowledge.com/ cop3m2a.htm

(5) Hinrichs, R. (1997) 'Intranets What's the bottom-line?', Sun Micro Systems, Prentice Hall.

(6) Powerpoint presentation available from author, E-mail wcbn007@easynet.co.uk

(7) http://www.cluetrain.com; and Locke, C., Levine, R. Searls, D., Weinberger, D. (2000) 'The Cluetrain Manifesto', Perseus.

(8) Collins, J. and Porras, J. (1994) 'Built to Last', Harperbusiness.

(9) Jensen, W. (2000) 'Simplicity: The New Competitive Advantage in a World of More, Better, Faster', Perseus; 
also http://www.simplerwork.com

(10) Petzinger, T. (1999) 'The New Pioneers: The Men and Women who are Transforming the Workplace and Marketplace'; also http://www.petzinger.com

(11) Mendelson, H. and Ziegler, J. (1999) 'Survival of the Smartest', Wiley.

(12) Tapscott, D. (1999) 'Creating Value in the Network Economy', Harvard Business School Press.

(13) Macrae, C (2000) 'Chartering interactive marketing's 21st Century', Interactive Marketing, Volume 1, Number 3.

(14) (1998) Special Triple Issue on Employee Brand Reality. The Journal of Marketing Management, Volume 15, Numbers 1-3.

(15) Mitchell, A (2000 in prep.) 'Win-Win Marketing'.
(16) http://www.topica.com/lists/cluetrain

(17) See eg, Washington Post (1999) 'EToys vs Etoy: A Clash of Commerce and Art', 10th December. http://washingtonpost.com/wpdyn/business/A39614-1999Dec9.html

(18) Allen, D. (1999) 'Enterprise Alignment', 3rd International Corporate Reputation Conference, Puerto Rico.

(19) SCAN (1999) Survey of Brand and Communication Management, Netherlands. Further info: E-mail: m.ligtenbarg@scan.nl

(20) (1998) Special Brand Valuation Issue, The Journal of Brand Management, Volume 5. Number 4.

(21) Macrae, C. (1996) 'MELNET96 invites you to contribute to the brand learning organisation', The Journal of Brand Management, Volume 3, Number 4. 